\title{
The Role of Social Engagement in the Development of Significant Architectural Objects
}

\author{
Ilze Miķelsone, Riga Technical University
}

\begin{abstract}
Social engagement and public participation is perceived as emerging social concern and coincidental annoyance for architects during the design and building processes. In the development of objects of public importance, especially those of ambiguous assessments, the knowledge of participatory methods, institutional support options, and knowledge of public relations and media literacy becomes an important element in contemporary architectural practice. Latvia's legislation ensures standard public participation procedure in a unified system within the attribute of "significant architectural object". This study attempts to recognize the origin and structure of multi-layered topic when the involvement of a wider public is applied in the development of architectural objects. It collects generally known major failures and maps component attributes within three stages. The Conclusion presents several observations on main research question, how the development of notable architectural objects in the local market is de facto affected by engagement of wider public.
\end{abstract}

Keywords - Social engagement in architecture, public participation procedure, public response to architecture, public discussion about architecture.

\section{INTRODUCTION}

Debating is the foundation of a democratic system. Public participation concept in development proposals of built environment is a globally and locally compelling process that emerged in the second half of the previous century. In the European Union the rights to be informed and influence processes by public opinion with regard to substantial matters have become a standard with international perspective [1] that applies to most of industries, including architecture. Today's processes demonstrate that only a few public built environment projects can go ahead without public participation [2], [3].

Public participatory concept within built environment industry has largely formed on the basis of the planning management concept known as "top-down and bottom-up planning" [4]. It includes the tasks of personalization of space and evaluation of inhabitant interests. Participation ensures that the society itself, knowing local conditions best, will be indicating to the local government the solutions that meet the interests of the areas of sustainable development in its best [5], [6].

Meanwhile, public participation as a legal procedure has become an element in a larger field of engagement opportunities. Aligning development investments with the interests of state, society and individuals generally represents an example of a very intrinsic relationship, maintaining significant extra resources, bringing extra risks and confusion, and may even completely discharge the intentions. Step by step, through the legislation, it has become a bureaucratic service where the rights to partic- ipate often are manifested in various forms beyond services of market economy.

In the criticisms about interest alignment cases at national level, the recognized common challenges are poor communication between the developers and the authorities, poor ability and willingness of the society to get involved, inability to make politically inconvenient decisions, ambiguous financing priorities, vaguely interpreted legal framework and others. These common issues are also complemented by internal communication challenges in the professional community. Representatives of the Latvian Association of Architects often mention the issue of poor activity and emphasize that it is not easy to find a compromise in important matters having more than 500 members [7]. In the criticisms regarding interest alignment cases in building intentions the main identified problems generally are set as formalism, low capacity and certain topic range of affected community [8]-[10]. In the criticisms about specific interest alignment cases the observations also show a multi-layered picture of public activities regarding building intention project development. Such specific cases typically refer to the development of socially significant architectural objects.

The research analyses the common strategy in Latvia regarding social engagement and public participation, and analyses the correlation between the components of social engagement services and real impact. The object of the study is socially significant architectural objects. The subject of the study is the components of social engagement management in building development in Latvia in the $21^{\text {st }}$ century. The aim of the study is to analyse the role of the subject within the development of the object.

\section{Research Methodology}

The research was conducted using theoretical and empirical methods. The basic parameters of both object and subject were defined, structured and assessed in the theoretical part of the research. In this study the process is characterized by three generally accepted stages of public engagement where the format of implementation of each stage describes the way this process takes place and develops a certain role. Stage in this article means a separate following part of public engagement process. In other words, in this research all three stages represent the topical parts of "social engagement" process (Fig. 1).

Stage 1 comprises legal and administratively fixed public participatory procedures, incorporated in the planning documents of Latvia since 1995 [11], [12]. It includes information about the development intention of a certain property and provides the 


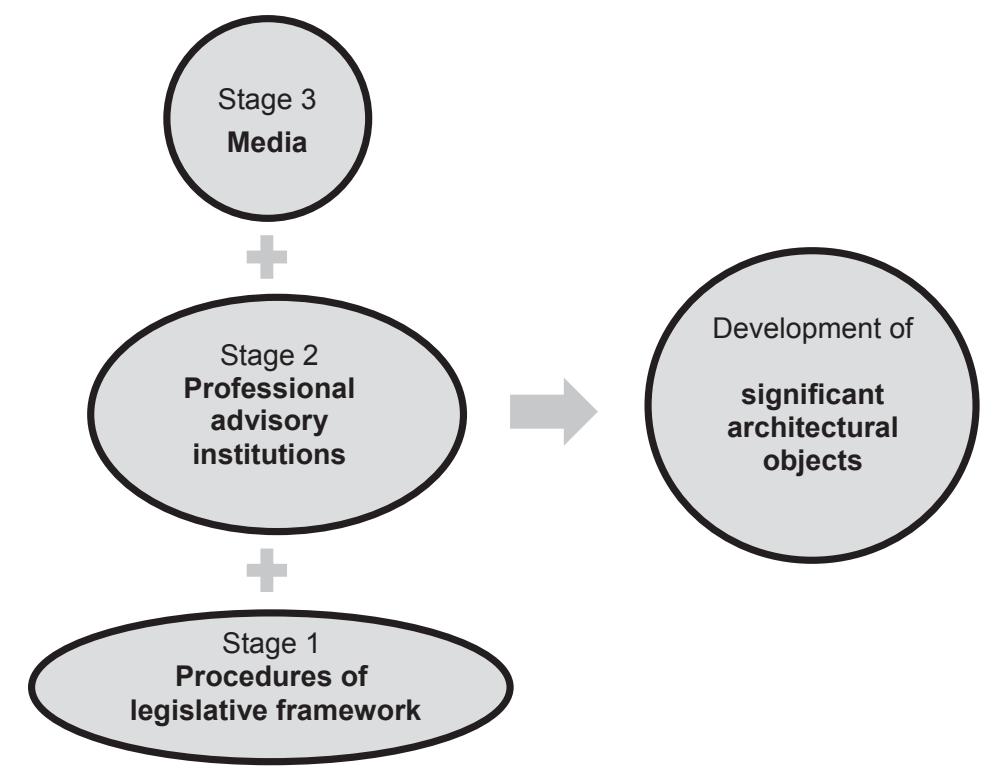

Fig. 1. Stages of public engagement used in the development of significant architectural objects [Picture: I.Miķelsone].

mechanism for the involvement of wider public. In the Construction Law this stage is called "public discussion" and is commonly understood as "public participation" [13], [14]. Several municipalities provide additional explanatory descriptions [15].

Stage 2 relates to the debate among the professionals and experts of different organizations. It includes the supportive institutional service, which functions either as a debate platform or provides professional consultations and informs about certain architectural problems. This stage is commonly understood as "public professional advisory" [16]-[22].

Stage 3 includes providing and distribution of information and exchange of opinions in the media. It supports interests and initiative driven activities, attracts attention and influences public opinion. This stage is commonly understood as "public activity" [23], [24].

The Research Basis is based on the locally most notable "public trials" of the last twenty years, which provided exchange of opinions on the development of specific buildings and were reflected in Latvian press and in different media groups. The selection of objects included in the study base was determined by the media awareness fact, reaching the threshold of 10-100 reports, and the fact that most of the objects included in this study formally correctly accomplished the Stage 1 - public involvement in their development, as well as applied and implemented the Stage 2. The tasks of the study are:

1) to provide an insight in previous criticisms of public participatory concept;

2) to systemize the components of transmission of the opinion of a wider public;

3) to give a particular insight in the characteristics of each component;

4) to verify the role of social engagement in correlation with the components in case studies.
This study attempts to recognize the component attributes, by which the development of notable architectural objects is de facto affected in case the involvement of a wider public is applied. The data on relevant building examples are generally analysed in the empirical part of the study.

\section{Previous Research}

The public participation is wide topic both in practical and theoretical field. The dialogue-oriented planning, which includes the participation and involvement of the users and other stakeholders in the process of design and planning, is being used since the 1960s. At first, they were developed in the US, the UK and the Netherlands, later in Germany. Despite the common source and ground of the concept, the participation in planning and building industries in practice is conceptually separated. This paper reflects information only in regard to construction industry.

Concerning Stage 1, several locally orientated investigations have been done on this subject in the context of practice in Latvia [5], [6], [8], mostly referring to the steps of legislative procedures. A number of studies express doubts whether public participation makes building projects more effective. The main criticism is directed to the fact that, despite theoretical concerns of the obligatory instrument for providing process transparency, quality of the certain product and alignment of interests, it does not work as expected. In fact, reverse correlation is observed in measurable returns of bureaucratic contribution. The state and municipalities have provided notable administrative input in developing legal and obligatory social participation instruments. Meanwhile, there are a growing number of cases when practical steps in public discussion process are taken, but the outcome does not satisfy the parties. Actual public discussions about architecture take place outside the created legal system, often after the legal procedure 
has been exercised. The main identified problems in achieving the goals of public participation concept include a) low capacity of local governments to involve the public; b) formal approach of municipalities to public participation; c) dominance of private interests in public participation process; d) inability to measure objectivity of citizens' dissatisfaction; e) developer's inability to answer to all questions of citizens; f) developer's tendency to hide information in order to minimize the level of attention; g) lack of regulations obliging the developer to follow citizens' opinions; h) inelasticity, where in case of disagreement, final decision made by authorities can be proceeded only in the court.

Concerning Stage 2, local investigation on aspects of institutional professional advisory concerning social engagement in the development of public buildings has not been published. This stage often refers to special cases or only to local or international architectural competition procedures.

Concerning Stage 3, local investigations on aspects of media regarding social engagement in the development of public buildings have not been published. The contemporary iconic review on public participation in construction industry in a longer time period was presented by the architecture firm Herzog \& de Meuron at the Venice Biennale 2012 [25]. The exposition title "Elbphilharmonie - the construction site as a common ground of diverging interests" provoked a question - what does it mean for a piece of architecture to be a part of the fourth power today, when it no longer comes to journalism, but mediology, communication culture and the information society [26]. The exhibition presents the significant project of multifunctional concert hall without taking a stand or attempting to analyse the complexities of its evolution. The only comments provided were uncensored press reports, demonstrating that this project has been a focus of public interest and ongoing debate for years. The architects explained that difficulties in the planning and building process caused the construction of the building to cease temporarily in November 2011, so they chose to present it at the biennale to draw attention to these issues and their effect on the architectural industry [26].

\section{Components of Social Engagement}

To bring clarity in the truly complex concept of social engagement in the development of significant objects works in practice, the components of the topic in first are conditionally structured in two groups (Fig. 2), as Base Component and Management Component.

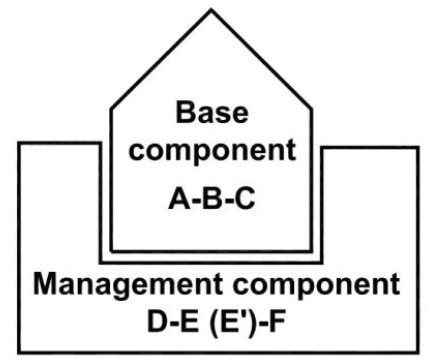

Fig. 2. Components of the tepie are conditionally struetured in two groups [Picture: I.Mikselsone].
The first group of Base Component is defined by parameters Fig. 2.: A-B-C, the second group of Management Component is defined by parameters Fog. 2.: D-E (E')-F. Each of the parameters is analysed separately.

Parameters of the first component (Fig. 3) are the basic units of the process. In order to realize the public engagement, there have to be at least two parties - a party that initiates communication and a party that responds to the invitation, and at least one debate object.

Parameters of the second component (Fig. 4) systemize the additional units of process management, such as relevance and scale, stages, formats and tools, issues and thematic sets.

\section{A. Parameter A - Foundation and Motivation for Invitation}

In Latvia since 1995, public discussion concerning built environment processes has been determined by law, covered by institutional support, and special procedure. The process of public discussion on the construction conception is determined by Cabinet Regulations No. 671, adopted in 2014 The Construction Law [13] determines the principle of public participation - public discussion on the concept of construction is provided in cases that are determined in this law. The same law stipulates, - "for enforcement of the Law the Cabinet shall issue special construction regulations determining the cases when the public must be informed regarding the construction conception, and the procedures for such informing" and determines, - "if construction of an object is proposed next to residential or public building, which may cause significant impact (smell, noise, vibration or pollution of another kind), but which has not undergone an environmental impact assessment, the building authority shall ensure public discussion of the construction conception and only afterwards take a decision on the construction conception of the proposed object. The local government may provide in the binding regulations also other cases when public discussion of a construction conception must be organized".

Until so far the procedure includes a clear process of its applicability [27]-[29]. The involvement and functioning of professional advisories differs in each particular case. The motivation of the third parties and the activists who settle matters within or outside the framework of the proposed procedure also differs in each particular case. Last but not least, - none of the regulations obliges to actually implement the opinion, which origins from the public.

\section{B. Parameter B - Object and Its Stated Significance}

This parameter provides information, which is legally stated regarding the definition of "significant", and analyses how the status of national importance or its application criteria for buildings is defined in Latvian legislation. Until 30 September 2014, the definition of a building of public importance was determined in Section 25.2 of the "General Construction Regulations" (Cabinet Regulations No. 112). The definition specified that it is a) a building which has more than five above-ground stories; b) a public building, which is intended for more than one hundred inhabitants concurrently; c) a production or warehouse building 


\begin{tabular}{|c|c|c|c|c|c|c|c|c|}
\hline \multirow{4}{*}{ THE INITIATION } & \multirow{3}{*}{$\begin{array}{c}\begin{array}{c}\text { Institutional } \\
\text { by-law }\end{array} \\
\begin{array}{c}\text { Professional } \\
\text { NGOs }\end{array} \\
\end{array}$} & \multirow{4}{*}{ 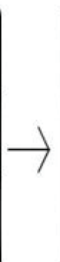 } & \multirow{4}{*}{\begin{tabular}{ll} 
& \multicolumn{1}{c}{} \\
\\
THE OBJECT \\
$-\quad$ Built \\
$-\quad$ In process \\
Cancelled \\
or Pending
\end{tabular}} & \multirow{2}{*}{\multicolumn{2}{|c|}{$\begin{array}{l}\text { Object of stated } \\
\text { significance } \\
\text { (III rd group object } \\
\text { in legislation) }\end{array}$}} & \multirow{4}{*}{$<$} & \multirow{4}{*}{ THE PUBLIC } & Society \\
\hline & & & & & & & & \multirow{2}{*}{ Affected community } \\
\hline & & & & \multicolumn{2}{|c|}{ Special location } & & & \\
\hline & $\begin{array}{l}\text { Third parties } \\
\text { and } \\
\text { the activists }\end{array}$ & & & $\begin{array}{l}\text { Private } \\
\text { funding }\end{array}$ & $\begin{array}{l}\text { Public } \\
\text { funding }\end{array}$ & & & Concerned community \\
\hline
\end{tabular}

Fig. 3. The base component: A - initiation of the discussion; B - the discussion object; $\mathrm{C}$ - the public, which is giving response [Picture: I.Mikelsone].



Fig. 4. The management component: D - relevance and scale of the discussion; E - discussion stages and communication format of stages; E' - discussion implementation formats and tools; F - debate topics [Picture: I.Miķelsone].

with total area of more than $1000 \mathrm{~m}^{2}$; d) a tower; e) a bridge, an overpass, a tunnel which is longer than $100 \mathrm{~m}$; f) an underground structure of more than one story. Since the new "General Construction Regulations" (Cabinet Regulations No. 500) [31] came into effect on 19 August 2014, the previous concept of "public importance" is not binding anymore and is replaced by definition of "the IIIrd group object". The law determines the classification of buildings into groups depending on the complexity level of the construction and potential impact on human lives, health and environment. Status of stated significance is applied on the grounds of the following one or several applied criteria:

1. On the grounds of the Law on Territorial Development Planning. Paragraph VII of Section 1 of the Spatial Development Planning Law [30] defines the objects of national interest - these are territories and objects necessary to ensure essential public interests, protection and sustainable use of natural resources;

2. On the grounds of special location. It refers to objects intended in specific construction zone or historical zone and may change the historically determined landscape [35]. For example, Riga historical centre is included in the UNESCO World Heritage List, whereas implementation of this status is complemented by mandatory application of the procedure of architectural competition, - and thus the Stage 2 public involvement;

3. By number of floors and users. "The III rd group object" is structure with more than five floors meant for more than 100 people [31];

4. By typology. In the local building regulations each municipality may additionally determine application of public importance [32];

5. By public accessibility. Pursuant to Section 2.4 of Cabinet Regulations No. 311 "Regulations on the Latvian building norm LBN 208-15 “Public structures” of 30.06.2015 [33], a public building or structure is a building or a structure, where $50 \%$ or more of the total area of the building or structure is intended for the purpose of a public function, or an engineering structure designed for public use. Pursuant to Section 1.4 of the aforementioned regulations, a public space is a non-residential space accessible to the public, where visitors (for example, spectators, patients, customers, buyers, passengers, students, pupils) may stay temporarily and receive different services;

6. By source of funding (when public finances are being involved and public competition or tender is obligatory for the design of the building) [34]. Implementation of this 
clause is complemented by mandatory application of the procedure of architectural competition;

7. On other special occasions (when the object is of national importance and is granted special status by the individually devoted law). In some cases, objects are assigned a special status, related only to particular objects. For example, Section 6 of the Law on Latvian Occupation $\mathrm{Mu}-$ seum [36] stipulates that the perspective object "Memorial complex for the commemoration of the victims of Soviet occupation" has the status of an object of national interest. Also, Section 4 of the Law on Implementation of the Latvian National Library Project [37] stipulates that the Latvian National Library building shall be constructed particularly on the grounds of the design of "Latvian National Library" developed by architect G. Birkerts.

\section{Parameter C - The Public Giving Response}

According to the concept of democracy and civil liability, the target groups of public opinion exchange include all society as citizens and stakeholders. In reality, persuasive segregation of society and the concept of liberal understanding are more applicable. The characteristics of average service user of Stage 1 may be classified as target groups where, with rare exceptions, participation is delegated to representatives from the affected and/or the concerned community. The participants of public discussion procedure are characterized in terms of difference regarding the level of interest. They may be differing in having a) no or insignificant interest; b) directly affected person's interest, typically represented by a claim or complaint; c) indirectly involved person's interest, typically represented by suggestion or opinion; d) special interest in subject or object, represented by different focus, understanding or attitude, different value priorities.

\section{Parameter D - Relevance and Scale}

This parameter describes the origin of institutional service for public discussion in Latvia and states the difference between "the public participation concerning planning documents" and "the public discussion concerning building intention proposals". Larger municipalities offer two procedures of different scale, which are governed by two different departments.

The first scale of cases relates to the public participation procedure, and concerns such planning documents as local plans, territory planning documents and projects of strategy and development programs. The service of this scale is provided by city council, and is in the competence of the development department. The legislative procedure determines the way in which citizens have the opportunity to participate in public consultation and decision-making concerning the planned construction of the environment for their place of residence within the administrative territory [11], [12].

The cases of the second scale relate to the public discussion procedure and concern such planning documents as detailed plan (Detalsplāns) projects and building intention project (Būvniecības iecere) documents. This service is provided by the city council, and is in the competence of the Construction Board (Būvvalde).
The aim of this procedure is "to coordinate the interests of the public and construction proposal, which cannot happen by prohibiting the construction, but is possible by making adjustments to the construction intention, while respecting the spatial plan developed by the official authorities and specific building regulations" [13], [14].

\section{E. Parameter E - Stages of Acquiring/Influencing the Public Opinion}

There might be different ways of influencing and discussing the buildings in the design stage and later, but in this article, public discussion in regard to building intention objects are divided into three stages, where the format of implementation of each stage describes the way this process takes place.

\section{F. Parameter E' - Tools: Instruments and Mechanisms}

Instruments and mechanisms refer to the totality of means used to communicate with a wider public.

1. Stage 1. The first stage of dealing with public response is the procedure of communication with the wider public with the purpose of informing and gaining general acceptance.

\section{G. Instrument, Format and Tools: Legally Regulated Proce-} dure

Representatives: Public participation instrument provided by an institutional service has a statutory status, and at the level of building intention proposal it is mainly dealing with interests between the proponent, the public and the city. Access to this procedure mostly automatically means that the process is legal in regard to the strategic and planning stage. Opinions may be expressed by using e-service or during meetings.

Features and circumstances: Forms of communication include published announcement, published results and an information board set up at the construction site. The outcome includes possible additional conditions, decision and summary overview. Local municipalities admit that public interest might be minimal in most cases, but also recognize that there is an increase in the number of cases when public pressure is great and long-lasting. Generally, this instrument is mostly suitable for average cases where collision of interests is possible. Possible claims for improvements relate to practical subjects like tree felling, proper keeping of green areas, neighbourly relations and shading. During this stage, despite criticism [26], [27], most of arguments normally are preventable. Unfortunately, in most cases the summarized and detailed results of the public discussion procedure are not published, available online or presented and discussed publically.

2. Stage 2. Apart from the formal obligatory procedure, common places for professional consultations and debate are made available by supportive institutional and nongovernmental services in Latvia. Documented expert opinion as a stage within social engagement in the development of significant architectural objects is performed by supervising authorities, including various expert commissions, 
and is commonly used in most of the major local debate platforms, including architecture competition juries.

Instrument, format and tools: Representative institutions and expert groups of industry.

Representatives: Existing institutional services and non-governmental institutions responsible for the resolutions of the proposed built environment.

Major institutional services:

- $\quad$ National Board for Architecture (Arhitektūras Padome) under the Ministry of Culture of the Republic of Latvia runs the debate on political aspects [16];

- City Development Committee (Domes Attīstības komite$j a)$ of Riga City Council runs the debate regarding city development and territory planning [17];

- $\quad$ State Inspection for Heritage Protection (Valsts kultūras piemineklı aizsardzības inspekcija, VKPAI) supervises the activities regarding historical aspects. The Council for Preservation and Development of Riga Historic Centre (Rīgas vēsturiskā centra saglabāšanas un attīstības padome, RVC SAP) was established within the Inspection. The competence of the Council is "to promote and provide the opinion on spatial planning issues in the historic centre of Riga, to assess the intentions of the new buildings, reconstruction or demolition of buildings and structures, as well as install and restore monuments in the historic centre of Riga and its protection zone, provide the opinion to the Riga City Council regarding different effects of modifications made to the cultural and historical environment, as well as other rights in accordance with the Law on Preservation and Protection of the Historical Centre of Riga" [18];

- A special City Architect's Bureau (Rìgas pilsētas arhitekta birojs, $R P A B$ ) was established to perform the functions of a professional advisory body that operates in accordance with the laws and regulations of the Republic of Latvia. The aims and objectives of the agency have been determined by Riga City Council. Among others, the principal task of the Bureau is to "form and express professional opinion, as well as initiate an open debate on implementation of important construction intentions and other architectural issues in the city of Riga, which involve interests of different stakeholders" [12]. According to the data available on the official website, the Bureau is, run by at least seven members; since 2006, the meetings have been held 4-14 times a year. All protocols are available online [19].

Major involved non-governmental institutions are:

- Latvian Association of Architects (Arhitektu savienība) [20] and the Council of the Creative Unions of Latvia (Latvijas Radošo apvienību padome) [21];

- Such organizations as the National Council for Construction [22], Strategic Partnership for Construction Development, Latvian Association of Builders, Latvian Association of Civil Engineers, Latvian Association of Structural Designers, Association of Construction Material Manufacturers, Latvian Association of Heating, Gas and Water
Technology Engineers, Latvian Road Builders Association, Latvian Sustainable Construction Council, Latvian Association of Engineering Consultants, Latvian Chamber of Commerce and Trade, Building Design and Construction Council and Association of Transport Structure Engineers have expressed interest and eligibility to participate in the public participation process according to their competence.

Features and circumstances: Supportive institutional service as public discussion mode is used for participation and debate among professional experts and officials. It is mostly used and suitable to exert professionally related influence on objects and subjects of national importance, such as visionary development proposals, public culture, infrastructure or other objects. It has both statutory and initiative driven status, and it is dealing with interests on case-to-case basis, but mainly when there are disagreements between the proponent and the city (or state). Opinions may be expressed during closed or semi-closed meetings. The form of communication includes published announcement, press releases, the results published on the website or none of these, depending on the relevant service provider and the case. The outcome includes decision review and summary overview.

Previously there have been no studies about any qualitative or quantitative indicators of this stage.

3. Stage 3. Apart from the formal obligatory procedures and common tables for professional debate within supportive institutional services, the third stage of public discussion interest and initiative-driven service manifests mainly within the domain of public relations. Definition of public relations in fact is an attempt to create public support for a certain activity, thing, institution, movement or idea. Such manifestation is known as communication management between the field representative or certain individuals and the rest of the society.

Representatives: journalists, opinion leaders, academics, representatives of the parties.

Instrument, format and tools: Mass media. Media functions take the form of daily press information, professional publications, press conferences, interviews, individual contacts, and television or radio broadcasts.

Features and circumstances: This part includes moral supervision, propaganda and public affairs, and is related to public discussion as advocacy, criticism and claims. The origin of metaphor about media as the fourth estate is generally considered to stem from 1787, when the Irish statesman, philosopher and political theorist Edmund Burke (1729-1797) the formulated triad of power (legislative, executive and judiciary) supplemented with the fourth - journalist estate [18]. The examples of strong involvement and powerful influence of media are proved by several public discussions about objects.

However, the level of activity that is used to involve the press, the level of product that is being published and the format of media, where the information exchange takes place - that all makes a difference. Often the media serve as a platform for representation of the interests of particular personalities. Academic studies 
and motivated articles on current building intentions are rather rare and mostly appear quite late. The most common ones are informative notices regarding the progress of an object, critical opinion articles on a subject related to the perspective object or battles between two opposing groups on whether the object should be developed at all.

\section{H. Parameter F - Issues: Thematic Sets}

The thematic set is a characteristic component of public discussion and criticism itself. Selections of gages might include political issues, environmental issues, lawful/unlawful issues, ethical issues, economical issues (costs) and architectural, functional and social topics. Observations indicate that discussions are usually focused on a few or sometimes even one issue that has been given priority in discussions, instead of a complex assessment of the object.

Within Stage 1 the public consultation procedures are institutionally created and designed as conversation between citizens and developers, proceeded with the help of the architect. The overview of characteristic thematic set mostly, but not always shows practical subjects, understandable to anyone.

Within Stage 2 the public discussion is institutionally created and designed for the conversation between the architect and experts, with participation of governmental structures. The overview of characteristic thematic set shows complicated and divisive subjects.

Within Stage 3 the discussion in public about architecture proposals is constituted by a real estate market component and takes the form of conversation between stakeholders or their representatives with the aim to attract positive or negative attention from wider public and achieve the set goal by creating social pressure. The topic within the debate might be multi-layered and might not concern architecture directly.

\section{Correlation of Components by Realization Status}

Verification of the role of social engagement was analysed also according to the status of realization. By this status object belongs to one of the three principal groups (Fig. 5):

a. Completed buildings [43]-[46];

b. Buildings under construction [38]-[42];

c. Cancelled or pending building projects [47]-[49].

Since different objects have been argued with different intensity, deliberated and discussed within several media forms and on several different topics, marked reference sources on object information are selected randomly from notably wider range available in media.

\section{Verification of The Role of Social Engagement}

The main research question of this study is about how the development of notable architectural objects in the local market is de facto affected by engagement of wider public. Due to the complexity of the subject character, the observations and con- clusions about aspects of potential role and influence indicators were observed generally, within the following schedule:

1. The fact of public involvement in the context of three stages:

- Successfully/unsuccessfully accomplished Stage 1. Completed public information debates, installed information stands, number of received feedback, number of considered feedback;

- Successfully/unsuccessfully accomplished Stage 2. Number of involved supporting institutions and responding non-governmental institutions, and number of issued documents;

- Successfully/unsuccessfully managed Stage 3. Low, average or high publicity indices.

2. Activity level of the involved public and the quality of the involvement content;

3. The possible reasons of activity, content and hierarchy of arguments;

4. The way objects have been positioned in the public domain - appreciation, critique or both;

5. The range of media groups involved;

6. The intensity of attention;

7. Possible role of force capability of different actors, - such as Opinion leaders, Project authors, Clients, Contractors, specific Publicists or even Public Relation managers.

\section{Conclusion}

Information provisioning and exchange with the wider public about building intentions of defined importance in Latvia is defined by law. The procedure and the relevance of procedure are both clearly defined and mostly implemented correctly.

Though, definition of "importance" on buildings is not accordingly responsible stipulated in existing legislation. Legislation defines "public building" and requirements for it, but does not provide direct and patent definition of "publicly and socially significant architectural object", which are not synonyms. Special cases may be stipulated by several normative features, but generally, according to the current legislation, public involvement concerning the development of socially significant architectural objects is incorporated in the same common practice as for any other typologies of the $3^{\text {rd }}$ group objects and according to Procurement Law.

Generally, the influence of the public discussion procedure or Stage 1 is mostly perceived as ambiguous and time consuming process. Local studies mostly stress that the aforementioned concept of a comprehensive idea of public participation has evolved to the level of ineffective institutional and bureaucratic service and this instrument is having particularly minor role in regard to the development of important objects. However, public representatives are given the opportunity to speak out and this is still the only practical way to inform the public.

The influence of professional advisory platforms or Stage 2 more likely plays practical role at the level of strategic resolutions and in determining the winner of the architectural compe- 
tition. The results of this stage also work as the "winning card" in contradictory disputes. Therefore, its influence is considered to be rather high.

The influence of the media domain or Stage 3 as practical power seems to be crucial both in positive moving of dubious and low quality projects and negative in terms of trigging off high quality projects. Special attention was paid to the cases when the Stage 3 has had been used not as neutral information carrier but as weapon, - influence tool or even as final desperate step when the other stages have failed to achieve visible results. Unfortunately, statement that this stage has certainly played notable role or any role in the development or hindering of specific objects cannot be verified by facts.

Pre-conditions of Stage 3 emergence always are closely connected with problematic processes - special location, process transparency, lawlessness, etc. On the one hand, media and journalists may work as "social police", highlighting otherwise suppressed problems. On the other hand, media market is used as a mechanism for attacking opponents and preceding public group conflicts. Thus, the project initiators, authors and stakeholders increasingly have to take into consideration also the risks of misguidance of projects. The cases of several abandoned projects show that, as a result of public activity, the process could be hindered for a certain time period. Though such assumptions cannot be attested and it should be considered, that the real cause of delay or cancel of object development does not relate to public activities as it seems to.

During the empirical research the most important conclusion was that, regardless of the general features and multiple groupings, none of the cases, which came into an active public sight, can be considered typical and mutually comparable within a group. The results on the role of social engagement within the context of three stages clearly demonstrate lack of consequence and predictability. Every object has a unique "set of importance" assigned to it and also unique "set of thematic issues" has been portrayed. Attempts to include these examples into a uniform local situation reflective typology have suffered failure.

The practice of several already completed objects indicates that regardless of high and negative public activity, any impact on the proceedings of the objects does not exist. The author considers, that in the conditions of increasing competiveness and disagreement in opinions, the value of the project success tends to increase dependency not so much on architectural or technical qualities, as on the process management skills, and likely relates to strategic political protection, type of funding and capability to influence or side-track the institutional and social decision making machinery.

\section{REFERENCES}

1. Public Participation in Europe : An international perspective, 2009 [online]. European Institute for public participation [cited 01.10.2016]. http:// www.partizipation.at/eipp_public_participation0.html

2. Hofmann, S. Architecture Is Participation : Die Baupiloten : Methods and Projects. Berlin: Jovis, 2015. 206 p.
3. Mickos, M. An architecture of participation, 2012 [online]. Opensource [cited 01.10.2016]. https://opensource.com/business/12/6/architecture-participation

4. Murray, M., Greer, J., Houston, D., McKay, S. and Murtagh, B. Bridging Top down and Bottom up : Modelling Community Preferences for a Dispersed Rural Settlement Pattern. European Planning Studies, 2009, 17 (3), pp. 441-462. Available also at: http://dx.doi. org/10.1080/09654310802618101

5. Litvins, G. Sabiedrības līdzdalība teritorijas plānošanas un būvniecības jautājumos [online]. Providus [cited 01.10.2016]. http://politika.lv/article/ sabiedribas-lidzdaliba-teritorijas-planosanas-un-buvniecibas-jautajumos

6. Lešinska, A. Sabiedrības informēšana par būvniecības iecerēm atbilstoši Būvniecības likumā noteiktajam, 2015 [online]. Providus [cited 01.10.2016]. http://providus.lv/article/monitorings-sabiedribas-informesana-par-buvniecibas-iecerem-atbilstosi-buvniecibas-likuma-noteiktajam\#comments_9346

7. Discussion in Architects House, organized by Latvia Association of Architects between NGO and project authors, the architects INDIA and 1.618 [online]. $A 4 D$ [cited 01.10.2016]. http://www.a4d.lv/lv/notikumi/1220

8. Mūriņš, S. Pētījums par sabiedrības iesaistes mehānismiem attīstības plānošanā un uzraudzībā vietējā līmen̄ī, 2013 [online]. Academia [cited 01.10.2016]. http://www.academia.edu

9. Brokane, L. Publiskā apspriešana : realitāte vai fikcija (published 14.08.2008) [online]. Rīgas Balss [cited 01.10.2016]. www.leta.lv/arhivs

10. Pelcmane, S., Ulberts V. Sabiedriskās apspriešanas : nopietni vai ķeksīša pēc? [online]. TV NET [cited 01.10.2016]. http://www.tvnet.lv/zinas/viedokli/293155-sabiedriskas_apspriesanas_nopietni_vai_keksisa_pec

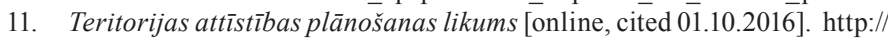
www.likumi.lv/doc.php?id=238807

12. MK noteikumi Nr. 970 "Sabiedrības līdzdalības kārtība attīstības plānošanas procesā", 25.08.2009. [online, cited 01.10.2016]. http://likumi.lv/doc.php?id=197033

13. The Construction Law of the Republic of Latvia (Büvniecības likums, 2013) [online, cited 01.10.2016]. http://likumi.lv/doc.php?id=258572

14. MK noteikumi Nr. 671 "Būvniecības ieceres publiskas apspriešanas kārtība”, 2014 [online, cited 01.10.2016]. http://likumi.lv/ta/id/269978-buvniecibas-ieceres-publiskas-apspriesanas-kartiba

15. Būvniecības ieceres publiska apspriešana [online]. Pašvaldības pakalpojumu portāls [cited 01.10.2016]. https://www.eriga.lv

16. Nacionālās arhitektūras padomes nolikums [online]. Kultūras ministrija [cited 01.10.2016]. https://www.km.gov.lv/lv/kultura/arhitektura/padome

17. City Development Committee of Riga City Council [online, cited 01.10.2016]. https://pasvaldiba.riga.lv/LV/Channels/Riga_Municipality/ Riga City Council/Committees/PilsetasAttKomiteja.htm

18. About inspection [online]. State Inspection for Heritage Protection [cited 01.10.2016]. http://mantojums.lv/lv/par-inspekciju/

19. RPAB, Pašvald̄̄bas aǵentūra Rīgas pilsētas arhitekta birojs [online, cited 01.10.2016]. http://www.arhitekts.riga.lv/

20. LAoA, The Latvian Association of Architects [online, cited 01.10.2016]. http://www.latarh.lv/

21. The Council of the Creative Unions of Latvia (Latvijas radošo savienību padome) [online, cited 01.10.2016]. http://design.lv/lv/partner/latvijas-radoso-savienibu-padome

22. The National Council for Construction (Būvniecības likums, 8.pants : Latvijas Būvniecības padome, Latvijas Būvniecības Padomes pilnvaras) [online]. Likumi [cited 01.10.2016]. http://likumi.lv/doc.php?id=258572

23. Veinberga, S. Komunikācijas traucējumi un to neprognozējamās sekas, 1999 [online]. Sandra Veinberga [cited 01.10.2016]. https://sandraveinberga.com/publicistika/komunikacijas-traucejumi-un-to-neprognozejamas-sekas/

24. Lasmane, S. Kāda ir mediju vara Latvijā? [online]. Delfi [cited 01.10.2016]. http://www.delfi.lv/news/national/politics/skaidrite-lasmane-kada-ir-mediju-vara-latvija.d?id=18856346

25. Basulto, D. Venice Biennale 2012 : Elbphilharmonie / Herzog \& de Meuron [online]. Archdaily [cited 01.10.2016]. http://www.archdaily.com/269531/ venice-biennale-2012-elbphilharmonie-herzog-de-meuron

26. Frearson, A. Elbphilharmonie by Herzog \& de Meuron at Venice Architecture Biennale [online]. Dezeen [cited 01.10.2016]. http://www.dezeen. 
com/2012/08/30/elbphilharmonie-by-herzog-de-meuron-at-venice-architecture-biennale-2012/

27. Būvniecības ieceres publiskā apspriešana [online, cited 01.10.2016]. www. eriga.lv

28. Zemgales plānošanas reǵions : Sabiedriskās apspriešanas organizēšanas un sabiedrības iesaistes ieteikumi, 2011 [online, cited 01.10.2016]. http:// www.kurzemesregions.lv/jomas/Teritorijas_attistibas_planosana/KPR_teritorijas_planojums/Teritorijas_attistibas_planosana/Metodiskie_ieteikumi_sabiedrisko_apspriesanu_organizesanai_un_sabiedribas_iesaistei

29. Gavena, I., Jekale, I.,Valdmane, I., Nikodemus, O. Metodiskais materiāls pašvaldības, iedzīvotāju un uzñēmēju interešu saskaņošana - sabiedriskā apspriešana kā instruments, 2011 [online, cited 01.10.2016]. http://www.kurzemesregions.lv

30. Teritorijas attīstības plānošanas likums (1.panta 7.punkts) [online, cited 01.10.2016]. https://likumi.lv/doc.php?id=238807

31. MK noteikumu Nr.500 "Vispārīgie būvnoteikumi" 1.pielikums [online, cited 01.10.2016]. https://likumi.lv/doc.php?id=269069

32. RDPAD. Teritorijas izmantošanas un apbūves noteikumi (TIAN), 2003 Rìgas Vēsturiskais centrs un tā aizsardzības zona (RVC AZ) (Land use and building regulations. Riga Historical centre and Protection zone, Regulation by Riga City Council City Development Department) [online, cited 01.10.2016]. www.rdpad.lv

33. MK noteikuтu Nr.311 "Noteikumi par Latvijas būvnormatīvu LBN 208-15 "Publiskas būves" 2.4. punkts [online, cited 01.10.2016]. https://m.likumi. $1 \mathrm{v} /$ doc.php?id=274995

34. Publisko iepirkumu likums, 2017 [online, cited 01.10.2016]. https://likumi. $1 \mathrm{v} / \mathrm{doc}$.php?id=287760

35. Rīgas vēsturiskā centra saglabāšanas un aizsardzības likums, 2003 [online, cited 01.10.2016]. http://likumi.lv/doc.php?id $=76001$

36. Latvijas Okupācijas muzeja likums [online, cited 01.10.2016]. https://likumi.lv/doc.php?id=146475

37. Latvijas Nacionālās bibliotēkas projekta īstenošanas likums [online, cited 01.10.2016]. https://likumi.lv/doc.php?id=75138

38. Hotel project in Grēcinieku street 25, Riga [online]. Arterritory [cited 01.10.2016]. http://www.arterritory.com/lv/teksti/raksti/4141-grecinieku_25_saga ;

39. Hotel project in Grēcinieku street 25, Riga [online]. Delfi [cited 01.10.2016]. http://m.delfi.lv/bizness/article.php?id=48634419

40. Sākušies Rakstniecības un mūzikas muzeja rekonstrukcijas darbi, 2016 [online]. Delfi [cited 01.10.2016]. http://www.delfi.lv/kultura/news/culturenvironment/sakusies-rakstniecibas-un-muzikas-muzeja-rekonstrukcijas-darbi.d?id $=47543791$

41. Apstrīd 20,5 miljonu vērtā muzeju krātuvju kompleksa būvniecības iepirkuma rezultātus, 2016 [online]. DB.LV [cited 01.10.2016]. http://www. db.lv/ipasums/apstrid-20-5-miljonu-verta-muzeju-kratuvju-kompleksa-buvniecibas-iepirkuma-rezultatus-444313

42. Melbārde : Ieilgušas iepirkuma procedūras dēl Rīgas pils 2018.gadā netiks atvērta [online]. TV NET [cited 01.10.2016]. http://www.tvnet.lv/zinas/ latvija/631893-melbarde_ieilgusas_iepirkuma_proceduras_del_rigas_ pils_2018gada_netiks_atverta

43. Gaismas pils izmaksas vairāk nekā desmit gados - 268 miljoni eiro, 2014 [online]. $L S M$ [cited 01.10.2016]. http://www.lsm.lv/lv/raksts/latvija/zinas/grafiks-gaismas-pils-izmaksas-vairak-neka-desmit-gados-268-miljo. a88285/.

44. Tračuma, B. Concert hall "Great Amber": Kukainīša anatomija jeb Liepājas daudzfunkcionālais centrs «Lielais dzintars» tuvplānā. Latvijas Būvniecība, 2016, Nr.1, 51.-63.lpp. ISSN 1691-4058

45. Mākslas muzeja rekonstrukcija ieilgs par gadu : izmaksas neprognozē, 2014 [online]. TV NET [cited 01.10.2016]. http://www.tvnet.lv/zinas/latvija/497299 makslas_muzeja_rekonstrukcija_ieilgs_par_gadu_izmaksas neprognoze

46. Rēzeknes koncertzāles celtniecībā nodarbināti nelegāli strādnieki, 2012 [online]. Pietiek [cited 01.10.2016]. http://www.pietiek.com/raksti/rezeknes_koncertzales_celtnieciba_nodarbinati_nelegali_stradnieki

47. Par lielveikala „Depo” būvniecību Jelgavā [online]. VKPAI [cited 01.10.2016].

http://mantojums.lv/lv/jaunumi/par-lielveikala-depo-buvniecibu-jelgava/

48 Rīgas arhitekts : Okupācijas muzeja piebūve nekad nav apspriesta ar sabiedrību, 2016 [online]. NRA [cited 01.10.2016]. http://nra.lv/latvija/ riga/163527-rigas-arhitekts-okupacijas-muzeja-piebuve-nekad-nav-apspriesta-ar-sabiedribu.htm

49. Ikšķiles novada kultūras centrs, 2008 [online]. A4D [cited 01.10.2016]. http://www.a4d.lv/lv/projekti/ikskiles_novada_kulturas_centrs/

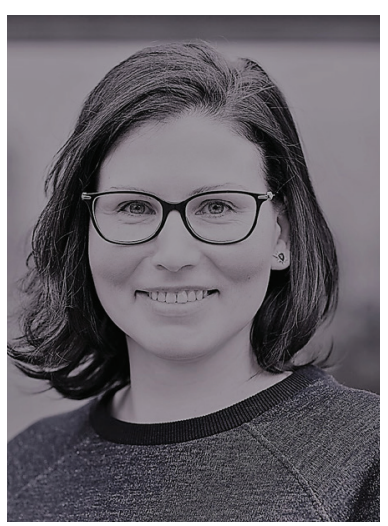

Ilze Mikselsone received the Professional Master Degree in Architecture from the Faculty of Architecture and Urban Planning, Riga Technical University, in 2012. Since 2012, she proceeds her doctoral studies at Riga Technical Unversity. Her main research interest is multi-layered concept of regional architecture.

She is a practising architect and is the author of the following publications:

- Custom-Made Patchwork Landscape: Entrepreneurial and Private Regionalism; Mokslas - Lietuvos ateitis, Vol. 2014, 6(3), pp. 290-302; ISSN: 2029-2341, https://doi. org/10.3846/mla.2014.041

- Quantitative and qualitative parameters of awards in architecture and construction industries of Latvia, Mokslas - Lietuvos ateitis, Vol. 2015, 7(1), pp. 89-100, https://doi.org/10.3846/mla.2015.724

- Methodology in attitudes assigned to architecture as distinctly regional; Architecture and Urban Planning, Vol. 11, 1, Published Online: 18 Sept 2016, https:// doi.org/10.1515/aup-2016-0006

- Architectural competitions as an instrument for heritage protection: the dynamics of competition taxonomy, Journal of Architecture and Urbanism, Published online: 14 Dec 2016, 40:4, 272-282, https://doi.org/10.3846/20297955.2 016.1246985

\section{Contact Data}

\section{Ilze Miḳelsone}

Faculty of Architecture

Riga Technical University

Address: 6 Ķīpsalas St., Riga, LV-1048, Latvia

Phone: +37129469655

E-mail: ilze@taktila.lv 